Cover Sheet for a Hanford

Historical Document

Released for Public Availability

Released 1994

Prepared for the U.S. Department of Energy under Contract DE-AC06-76RLO 1830

Pacific Northwest Laboratory Operated for the U.S. Department of Energy by Battelle Memorial Institute

\title{
\% Baftelle
}

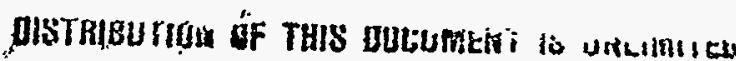

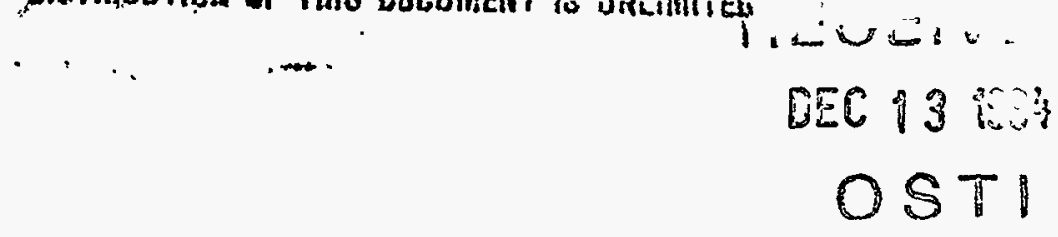




\section{DISCLAIMER}

This report was prepared as an account of work sponsored by an agency of the United States Government. Neither the United States Government nor any agency thereof, nor any of their employees, make any warranty, express or implied, or assumes any legal liability or responsibility for the accuracy, completeness, or usefulness of any information, apparatus, product, or process disclosed, or represents that its use would not infringe privately owned rights. Reference herein to any specific commercial product, process, or service by trade name, trademark, manufacturer, or otherwise does not necessarily constitute or imply its endorsement, recommendation, or favoring by the United States Government or any agency thereof. The views and opinions of authors expressed herein do not necessarily state or reflect those of the United States Government or any agency thereof. 


\section{DISCLAIMER}

Portions of this document may be illegible in electronic image products. Images are produced from the best available original document. 


\section{GENERAL ( If: ELETRIC}

MANFORD ATOMIC PRODUCTS OPERATION - RICHLAND, WASHINGTON

DOCUMENT NO.

HW-73906 RD 2

SERIES AND COPY NO.

Dhe

August 2, 1962

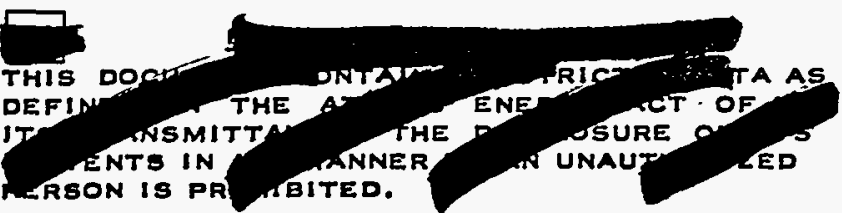

TITLE

DESIGN CRIIERIA

MODIFICATIOHS FOR USE OF ZIRCONIUM TUBES $100 \mathrm{~K}$ REACTORS

$\square$ OTH PICIA TSIFIEN FOR ON

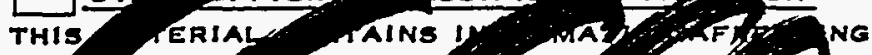
TH ATION NEFENSE THE HTED AATE $y$ AIN T MEANING THE RONA LA? TLE C. S.C., S. 793 794 HE ANSMISE OR REVE CON OF AICH ANY ANNER

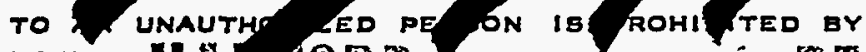

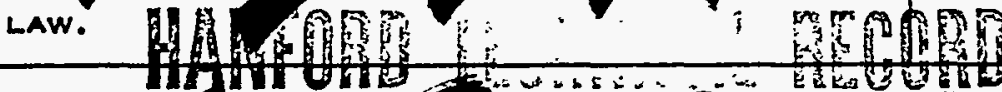

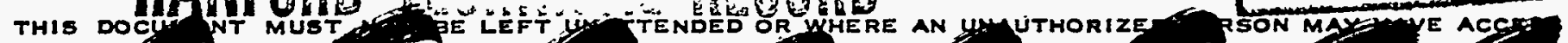

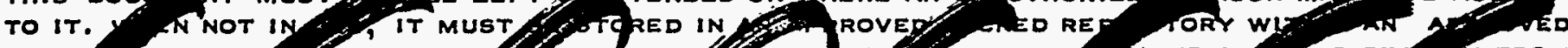

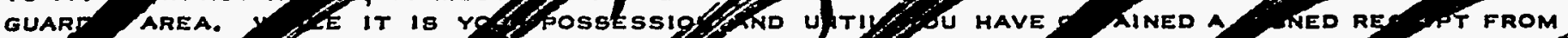

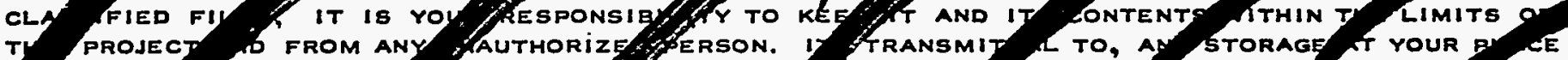
RESIDEY IS PROMIBI IT IS TO BE D LICATED. AF ADDITI AAL COPIE ARE RE GRED, STAIN TY I FROM THF LATED ISS VIG FILE. A! PERSONS ADING THS DOCUMENTARE RE,UESTED TO SIGN IN THE SPACE PIHOVIDED BEL

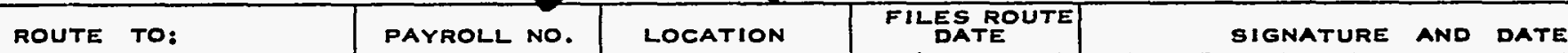
D.4-4)

Disposấ Date

Indefinite Retention
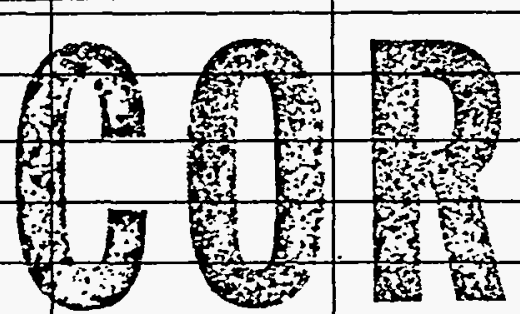

Authority
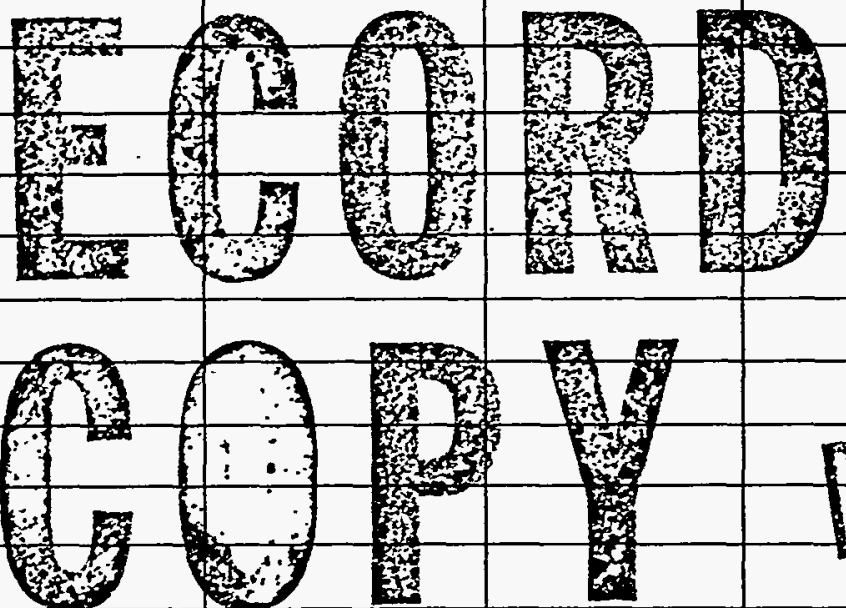

$n n^{-} 3 \quad x=2$

RETURN TO

TERHNICAL INFORMATION FILES SUING PILETIVG GOPY RECEIVED 700 AREA 
DESIGN CRITERIA

MODIFICATIONS FOR USE OF ZIRCOIIUII TUBES

$200 \mathrm{~K}$ REACTOPS

\section{DISTRIBUTION}

1. G. 0. Amy

2. E. R. Astley

3. R. S. Bell

4. J. E. Boyd

5. J. H. Brow

6. D. H. Curtiss

7. W. J. Ferguson

8. E. J. Filip

9. O. H. Greager

10. C. N. Gross

11. H. W. Heacock

12. A. W. Hervin

13. D. I. Hovorka

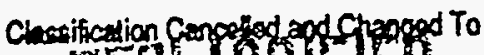

B Authority a CCE-PR-2,

4) $S$ esuis, $3-14-94$.

By Terri males, 5-17-94

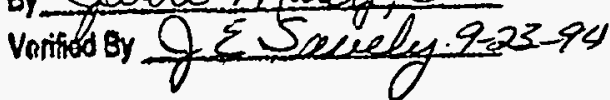

14. R. T. Jessen

15. A. R. Maguire

16. R. W. Reid

17. G. J. Rogers

18. M. H. Schack

19. O. C. Schroeder/C. A. Priode

20. W. Seeburger

21. F. A. R. Stainken

22. F. W. Van Wormer

23. W. W. Windsheimer

24. Record Center

25. 300 Area File

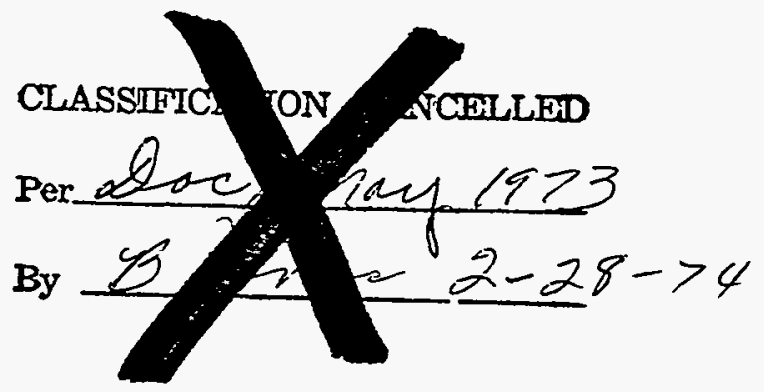

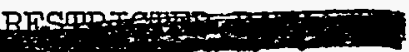
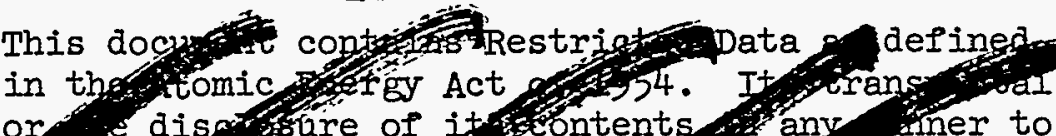

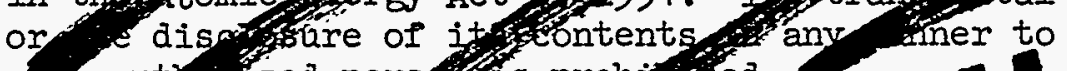

a lanaut ized persogs prob ited. 


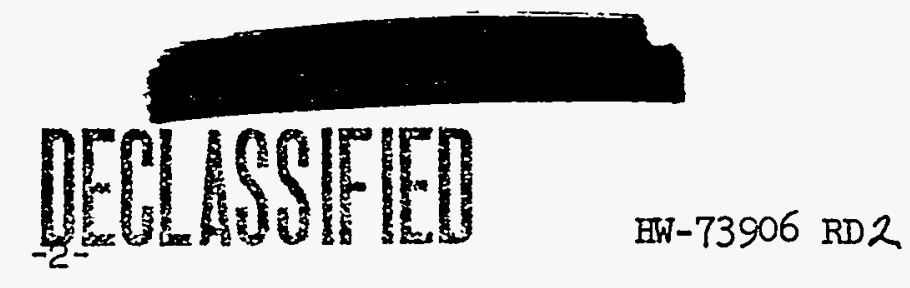

DESIGN CRITERIA

MODIFICATIONS FOR USE OF ZIRCONIUM TUBES

$100 \mathrm{~K}$ REACTORS

PREPARED BY:C Reactor Modification Design

DATE: $\quad 2-3 /-62$

FACIIITIES ENGINEERING SECTION

APPROVED BY:

DATE:

$7-3 /-62$

PROGRAM REPRESENTATIVES CONCURRENCE

DESIGN COUNCIL CONCURRENCE

DATE: $\quad 7-3 /-62$

DATE:

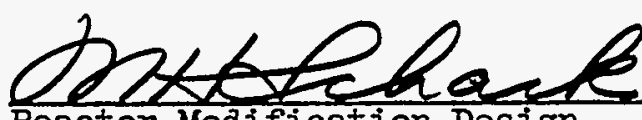

Reactor Modification Design

FACIIITIES ENGINERRING SECTION

FACIIITIES ENVGINEHERING SECPION

RESEARCH AND ENGINEERING SECTION

Project Engineering

FACILITIES ENGINEERING SECTION

1) 1 maxis

RESEARCH AND ENGINEERING SECTION

MANUFACIURING SECTION

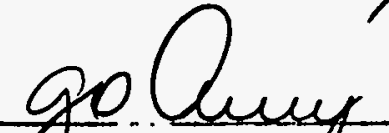

KE -FW REACTOR OPfRATION

MANUTF ACTURING SHCTION

APPLIED REACTOR ENGINEERING

MANUFACTURING SECTION 
DESIGN CRITERIA

MODIFICATIONS FOR USE OF ZIRCONIUM TUBES - 100-K REACTOR

\section{TABLE OF CONTEENTS}

\subsection{INTRODUCTION}

2.0 OBJECTIVE

3.0 GENERAI REQUIREMENTS AND CONSIDERATIONS

4.0 PROCESS AND FUNCTIONAI REQUIREMENTS

4.10 Process Tube Assemblies

4.11 General

4.12 Supplementary Control

4.13 Process Tube

4.14 Graphite Channel Preparation

4.15 Inlet Nozzle Assemblies

4.16 Outlet Nozzle Assemblies

4.17 Water Seals

4.18 Gas Seals

4.20 Replacement Spares

4.30 Charging Machine and Magazine Handling Facilities

4.40 Special Tools

5.0 BIBLIOGRAPHY

6.0 GRAPHS AND REFERENCE DRAWINGS 


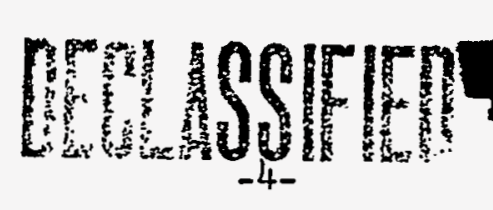

$\mathrm{HW}-73906 \mathrm{RD}$

\author{
DESIGN CRITERTA \\ MODIFICATIONS FOR USE OF ZIRCONIUM TUBES - 100-K REACTOR
}

\title{
1.0 INTRODUCTION
}

The following criteria defines the objectives, bases and functional requirements that shall govern the preparation of the final design for the zirconium process tube installation program at the $100-K$ Areas. As a result of this program, reduced operating costs and increased production can be achieved. The present central zone aluminum tubes in the $100-K$ Reactors require replacement every two to three years to prevent excessive failures resulting from the thinning of the tube walls by corrosion. Replacement of the aluminum central zone tubes with zirconium tubes which have a negligible corrosion rate will substantially reduce the need for tube replacement and the attendant loss of production. Installation of the ribless zirconium tubes will, in addition, permit increased production through the use of self-supported fuel elements of improved performance.

\subsection{OBJECTIVE}

The purpose of this document is to define the operational and technical requirements of the modified facilities and to outline the functional descriptions of the proposed equipment.

The objective in making these modifications is to provide the equipment and facilities necessary to permit operation of the 100-K Reactors with zirconium process tubes installed in the central zone regions.

\subsection{GENERAL REQUIREMENTS AND CONSTDERATIONS}

In order to reduce production Iosses associated with tube replacement activities, the 100-KE and 100-KW Reactors shall be modified for use of ribless zirconium process tubes. The zirconium process tube assembly shall be designed for the use of projection type selfsupported fuel elements. The tube replacement program shall be accomplished on a minimum cost and time basis and therefore modifications shall be restricted primarily to only those required for use of the new tubes and fuel elements.

All. equipment and piping shall be designed for operation consistent with standards of reactor operation, control and safety as set forth in the current editions of the following documents where applicable:

Process Standards, Reactor Technical Criteria and Basis Hanford Engineering.Standards
HW-46000-K

$\mathrm{HW}-74104$ 
This design criteria covers only the design of the process tube assembly and related supporting facilities and does not provide for the compliance of all features of reactor operation with the technical criteria referenced above.

Effects of predicted graphite distortion on tube life shall be assessed both from allowable stress and fuel charging considerations. Iocations and amounts of necessary graphite removal shall be established to insure appropriate tube life.

The modifications shall be compatible with the water plant capabilities resulting from the completion of Project CGI-883, Increased Process Water. Flow 100-K Area. The process water flow rates and reactor power levels"achievable under Project CGI-883 shall be retained.

In addition to the process tube assembly modifications, the following supporting facilities shall be provided.

(1) Magazine type charging machines and magazine handling equipment shall be provided.

(2) Special tools for graphite drilling, removing of existing aluminum tubes and installation and removal of new zirconium process tube assemblies shall be provided.

\subsection{PROCESS AND FUNCTIONAI REQUIREMENTSS}

\subsection{Process Tube Assemblies}

\subsection{General}

New zirconium process tubes will be installed in approximately 2365 central zone tube channels at each 100-K Reactor. The remaining channels in each reactor will consist of 562 existing ribbed aluminum tubes in the fringe zone and approximately 285 new ribbed aluminum tubes for spline control columns. The initial tube pattern and locations are shown for each reactor by drawings SK-1-2312l and SK-1-23123, which are attached in Section 6.0 or this document.

Self-supported Type KV fuel elements will be used in the zirconium tubes. The existing non self-supported I\&E type fuel elements will be used in the ribbed aluminum tubes.

The design operating conditions for the process tube assembly are as tabulated below: 
Inlet Water Temperature

Meximum Tube Outlet Water Temperature

Inlet Header Pressure @ \&

Outlet Header Pressure @ $\$$

Panellit Venturi Pressure

Tube Flow, Six Pump Operation

Effective Flow Tubes
$2 \mathrm{C}$ to $20 \mathrm{C}$

$120 \mathrm{C}$

440 psig

50 psig

265

$66.6 \mathrm{gpm}$

3000

Approximate flow characteristics of the inlet nozzle, fuel column and outlet nozzle shall be as shown by Figure 1, contained in Section 6.0.

The present process cooling water flow distribution zones shall be retained. Refinement of coolant flow distribution patterns may be desirable in conjunction with this program as indicated by future operational data.

\subsection{Supplementary Control}

The poison spline system presently in use at the $K$ Reactors for supplementary operational control shall be retained. Standard ribbed aluminum tubes and non-supported I\&E fuel elements will be used for the spline control columns in order to insure successful insertion of the splines into the process tube. The initial installation shall provide approximately 285 standard ribbed aluminum tubes for use with the poison splines. The location or these tubes is given by the reference drawings which are listed in Section 4.11. The presently used poison spline nozzle cap shall be installed on the inlet nozzle of the selected poison column tubes.

As operational data are obtained, the quantity of spline tubes may be reduced to about 200. The unneeded spline tubes would be replaced with ribless zirconium tubes during later routine scheduled outages.

\subsection{Process Tube}

The ribless zirconium process tube shall be as described by Specification HWS-5989. The outside diameter will be the same as the existing aluminum tube and the inside diameter will be nominally 1.724 inches. Thermal motion of the process tube shall be provided for by the motion of the existing gunbarrels. The installed length of the process tube shall be determined from thermal motion and future graphite distortion considerations. The existing Van Stone flange type of tube end connection and seal shall be retained and the flange outside diameter dimensions shall be the same as for the existing aluminum tubes. 
4.14 Graphite Channel Preparation

The predicted future graphite distortion during the extended corrosion life of the zirconium process tube may produce excessive bending of the tube within the graphite channels. Fuel sticking during charging or discharging or structural failure of the tube could result unless corrective graphite removal measures are accomplished orior to the zirconium tube installation. The effects of the future granhite distortion on the tube oderational capabilities shall be evaluated and the necessary graphite removal measures shall be determined to orovide an appropriate operational life for the process tube.

4.15 Inlet Nozzle Assembly

A new inlet nozzle assembly shall be provided for use with the zirconium tubes and shall be dimensionally compatible with the new self-supported fuel elements. The nozzle assembly shall consist of the nozzle body, end cap, seal plug and water inlet connector fitting. The nozzle body shall be designed for connection to the existing gunbarrel and nozzle flange components. The existing Van Stone flange tyoe seal for the process tube shall be retained. Provisions shall be made to prevent damage to fuel element supports as fuel elements pass through nozzle body. The hydraulic pressure losses of the inlet nozzle shall be kept to a minimum consistent with the overall design requirements.

The existing regular or spline tube type inlet nozzle assemblies shall be retained, as appropriate, for use with the aluminum tubes. Current design one piece lug rings and detented-slot type nozzle caps shall be installed on all existing nozzles. The existing inlet flexible connectors, venturi assemblies and crossheader piping shall be retained for use with all tube channels.

The existing nozzle flange to gunbarrel connection shall be modified to improve its reliability. The retaining rings which provide this connection have shown in-service failures in the form of radial cracks in the rings. The broken rings could become dislodged from their retaining groove and permit the nozzle assembly to become disconnected from the gunbarrel. The required modification shall be accomplished for all tube channels and shall utilize the existing nozzle flange and gunbarrel parts. 


\subsection{Outlet Nozzle Assembly}

The existing outlet nozzle assembly shall be modified for use with the zirconium process tubes by enlarging the bore to be dimensionally compatible with the new self-supported fuel elements. Provisions shall be made to prevent damage to the fuel element supports as fuel elements pass through the nozzle body. The hydraulic pressure losses of the outlet nozzle shall be kept to a minimum consistent with the bolling 'suppression requirements of the technical criteria.

A new dimensionally compatible seal plug shall be provided for use with the modified outlet nozzle.

The existing connectors, fittings and crossheaders shall be retained for use with all tube channels.

The existing outlet nozzle shall be retained for use with the ribbed aluminum tubes.

Current design one piece lug rings, and detented-slot type nozzle caps shall be installed on all outlet nozzles of both aluminum and zirconium tubes.

The nozzle flange to gunbarrel connection shall be modified as described for the inlet nozzle in order to improve the reliabllity of this connection.

\subsection{Water Seals}

Seal designs and materials for the process tube assembly shall be governed by the following considerations:

4.171 Where it is necessary to alter an existing 0-ring seal as part of the modification program, consideration shall be given to the use of materials which provide greater resistance to rear face radiation and temoerature enviroment than do elastomer materials. The use of elastomer type seals may be continued for inlet assembly applications.

4.172 Where an existing 0-ring seal is not affected by the modification program, the design shall not be altered and the seal shall be replaced with the existing elastomer type seal. An elastomer material of improved service IIfe shall be used if avallable.

4.173 The present type asbestos gasket shall be used for the process tube seal at the Van stone flange. The gasket dimensions shall be revised for use with the zirconium process tube assembly. 


\section{DEELLSSSFIED}

\subsection{Gas Seals}

The bellows type gas seal which seals between the gunbarrel and the extension sleeve shall be replaced with the same type seal of current design on both the inlet and outlet assemblies. The current design which is of silicone rubber has been in use on rear face applications and has demonstrated superfor service. Replacement of the gaskets at the centering flange joints by this program is considered impracticable because of the relative inaccessibility of these joints and the nature of the modification program.

\subsection{Construction Spares}

Some of the process tube assembly parts not modified by this program may become damaged during construction or may be found to be unserviceable. These parts which include RTD's and leads, venturi assemblies, connectors, nozzles and caps which are to be retained in kind, and miscellaneous fittings shall be replaced from maintenance spare parts. These parts shall be obtained in accordance with the approved designs currently in use at the time.

4.30 Charging Machine and Magazine Handling Facilities

4.31 Charging Machine

Three new charging machines including one spare machine shall be provided for each reactor. The machines shall be mounted on and shall travel on rails located on the charging platform. Each machine shall be capable of charging the appropriate fuel in both the ribbed aluminum tubes and the zirconium tubes at rates equivalent to or exceeding the existing rate of approximately 45 tubes per hour. The machine shall be designed to use preloaded fuel element magazines. Bach magazine shall contain sufficient fuel and dummy elements for a complete tube charge. The machine shall charge new elements into the process tube by a short stroke displacement method at the same time discharging the existing fuel column from the opposite end of the tube. The charging ram of the machine shall be capable of developing a thrust force of 4000 lbs. and shall have a maximum speed of 250 leet per minute. The machines shall be designed to perform the following functions: 


\section{Power Driven Functions}

1. Horizontal movement along charging platform rails.

2. Vertical adjustment of the charging barrel to permit charging of two horizontal tube rows from one charging platform position.

3. Alignment indexing of the fuel element magazines.

4. Charging of fuel elements into the inlet nozzles.

5. Retraction of charging barrel to permit movement of the charging platform.

Manual Operated Functions

1. Coupling of charging barrel to inlet nozzle.

2. Disconnection from hoist, positioning and connection to hoist of fuel magazines.

3. Manual operation of controls for initiation of power operated functions previously described.

Each charging machine shall not exceed 1500 lbs. in weight and shall be capable of being removed from the charging platform by overhead crane. Powered operations of the charging machine may be by pneumatic or electrical power. If electric power is utillzed the electrical equipment shall be of the totally enclosed water proof type.

Required seating forces for self-supported fuel elements shall be ascertained and new equipment shall be provided for charge seating if the existing is found to be inadequate.

4.32 Magazine Handling Facilities

A magazine handling system shall be provided to carry preloaded magazines, estimated to weigh approximately 350 pounds from pre-positioned pallets on the work area floor to the charging machines. The system shall provide for continuous type flow of the loaded magazines to each charging machine and return of the empty magazines from each machine to the work area floor by means of overhead monorall hoists. The magazine hoists shall be power driven and manually controlled by the operator. 


\subsection{Magazine Handling Facilities - (continued)}

The magazines shall be transported in containers which shall be manualiy connected to the monorail hoists. The handling system shall be capable of providing magazines to each charging machine at all positions of both the charging platform and the charging machines. The fuel handling facilities shall, under normal operation, supply loaded magazines at a rate which will prevent overloading of the charging platform.

4.40 Special Tools

Special tools will be required for use in the removal and installation of the process tube assembly equipment as provided for under this program. An estimate of the required tooling is given in the listing below. Many of these tools are now regularly in use at the present time, however, modifications to the current type tools and development of new tools will be required.

\section{General Iisting of Tooling Requirements}

1. Process tube cutting and removal tools for both aluminum and zirconium tubes.

2. Graphite channel broaching and drilling tools.

3. Process tube Insertion tools for both aluminum and zirconium tubes.

4. Cut off tools and Van stone flanging tools for both aluminum and zirconium tubes.

5. Gunbarrel flange removal, modification and in installation tools.

6. Gunbarrel grooving tool for flange retaining ring.

7. Rear nozzle broaching tools.

8. Tools for removing stuck fuel element charges.

9. Tools for tube and Van Stone flange pressure testing.

10. Miscellaneous hand tools such as wrenches for connector fittings and flange bolts. 


\subsection{BIBLIOGRAPHY}

Iisted in this section are the reference documents upon which these criteria are based.

Reference Documents Issued as of August 1, 1962

Doc. No.

$\mathrm{HW}-72864$

Letter

HW -59892

HW- 73651

Letter

Letter

Letter

Letter

HW-72088

Letter

HW-73198

Bumper Fuel Charging and Metal Handling System

Zirconium Thibe Requirements for $\mathrm{K}$ Reactor Retubing Program

K Area Hydraulic Working Curves

K Reactor Tube Bend Ijmits

Representatives Meeting Minutes No. 1

Representatives Meeting Minutes No. 2

Representatives Meeting Minutes No. 3

Representatives Meeting Minutes No. 4

Ioad, Distortion, Stress Relations for Circular Retaining Rings

Flow Tests of Revised Nozzle Designs for $\mathrm{K}$ Reactor

Design Test 1136, 105-K Zirconium Process Tube Channel Mockup \& Test

HW -73083

Design Test 1135, K Self Support Outlet Nozzle Strength Tests

HW- 72683

K Reactor Process Tube Nozzle Stresses

Letter 100-K Snap Rings

Author $\quad \frac{\text { Date }}{3--1-62}$

GF Bailey

$5-14-62$

$\pi$ Benson

$11-18-59$

JM Goff

5-11-62

AW Hervin

$5--3-62$

AW Hervin

$5-10-62$

AW Hervin

$5-10-62$

AW Hervin

$5-14-62$

WJ Iove

$12-29-61$

$5--9-62$

ED Waters

MH Schack

$3-30-62$

RM Baltrusch

$3-21-62$

PJ Hollifield

$2-14-62$

MC Fraser

$5-24-62$ 


\section{DEEL SFIFED}

HW-73906 RD

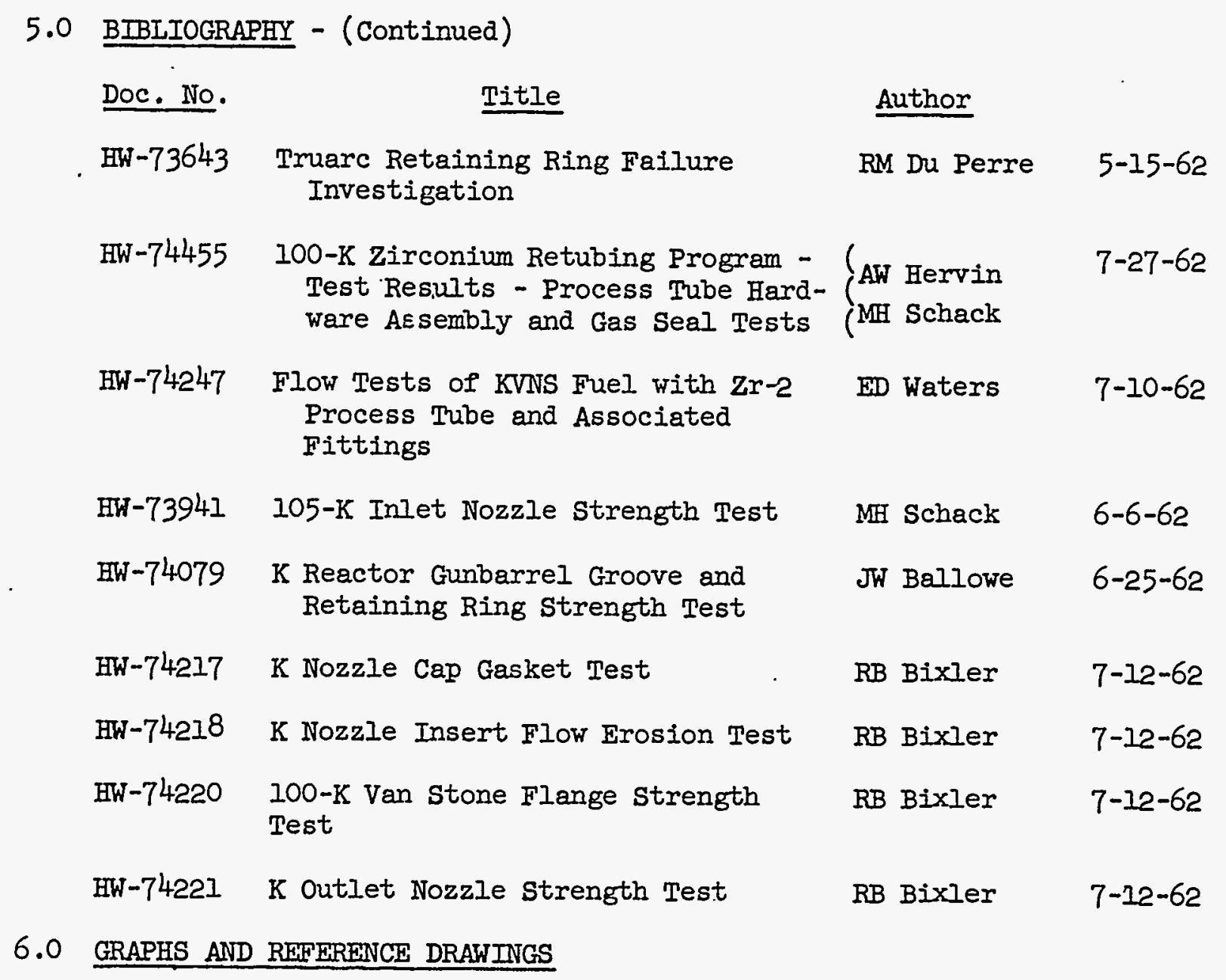

Iisted below and attached are the technical supporting data and drawings which amplify the description of the design requirements.

Figure 1

Figure 2

H $-1-33292$

SK-I-23100

SK-1-23I02

SK-1-23121

SK-I-23123
Process Tube Assembly Flow Characteristics

Fuel Handling Facilities

Metal Charger

Process Tube Inlet Assembly

Process Tube Outlet Assembly

Inlet Nozzle Arrangement 105-KK

Inlet Nozzle Arrangement 105-KE 


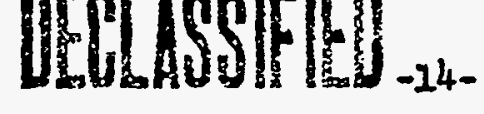

BNT-73906 RD

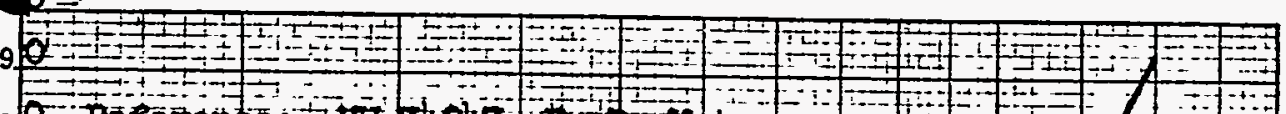

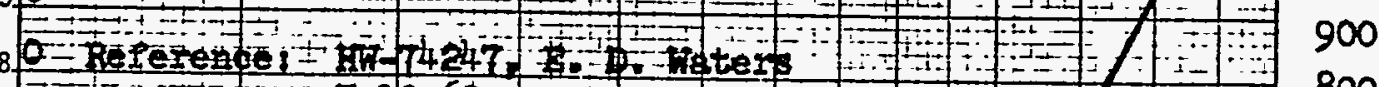

$770-627000$

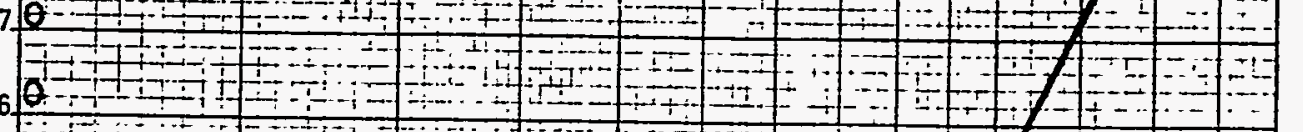

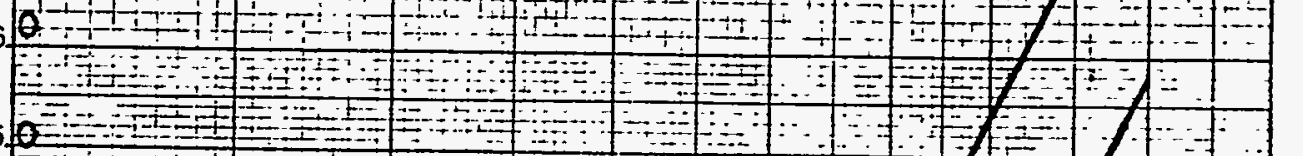

700

600

500

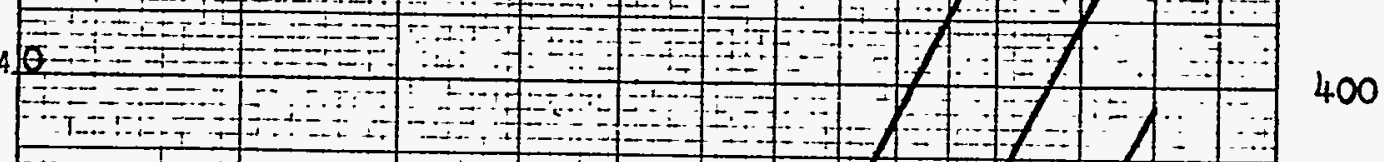

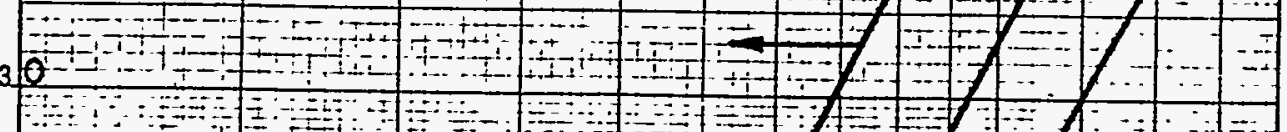

300

:

皆

1.5

2.5

$=$

20

- Front Header to Thibe

Inlot
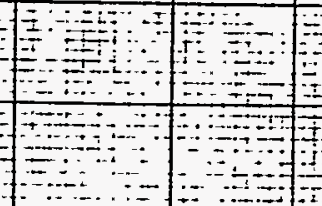

- in

9 ind Active Section
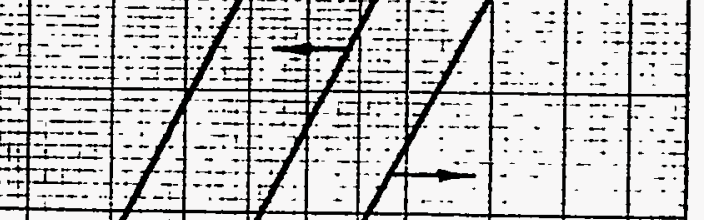

800

100

60

- of Aetive section

50

40

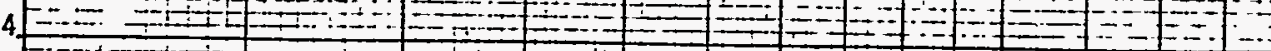

-

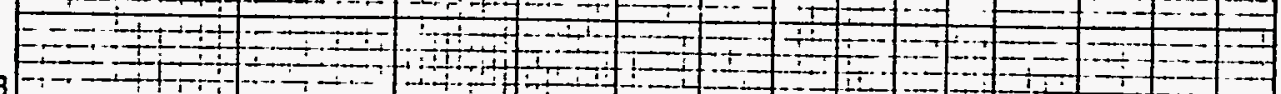

30

$2.5-1+1+1$

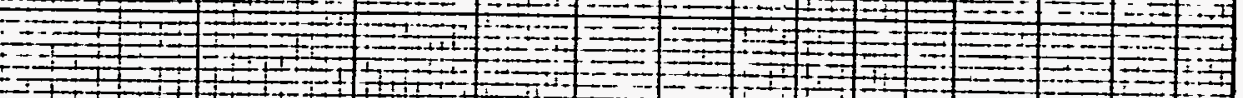

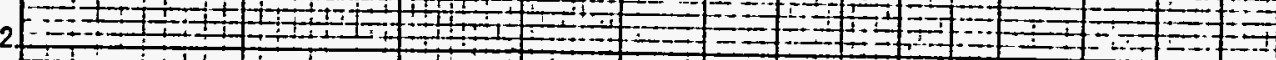

20

1.5

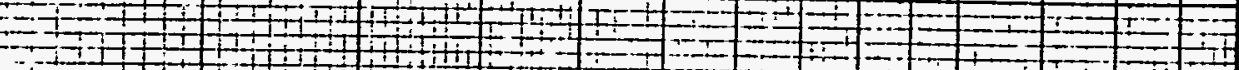

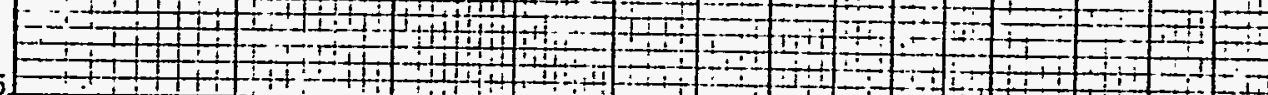

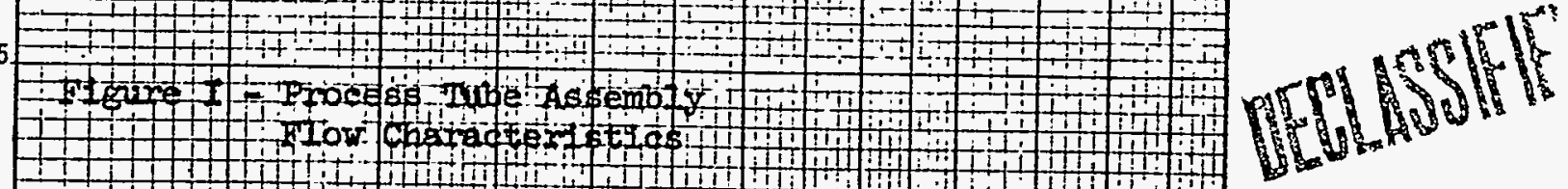

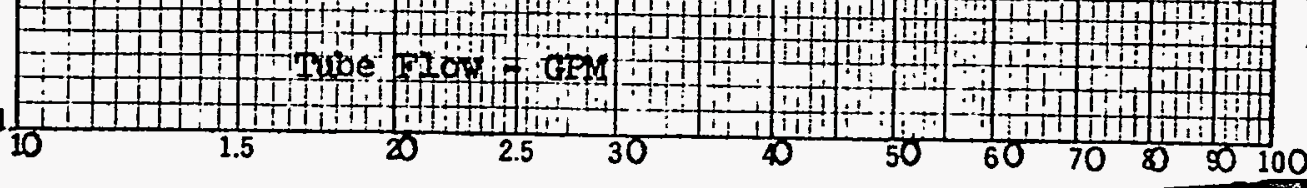




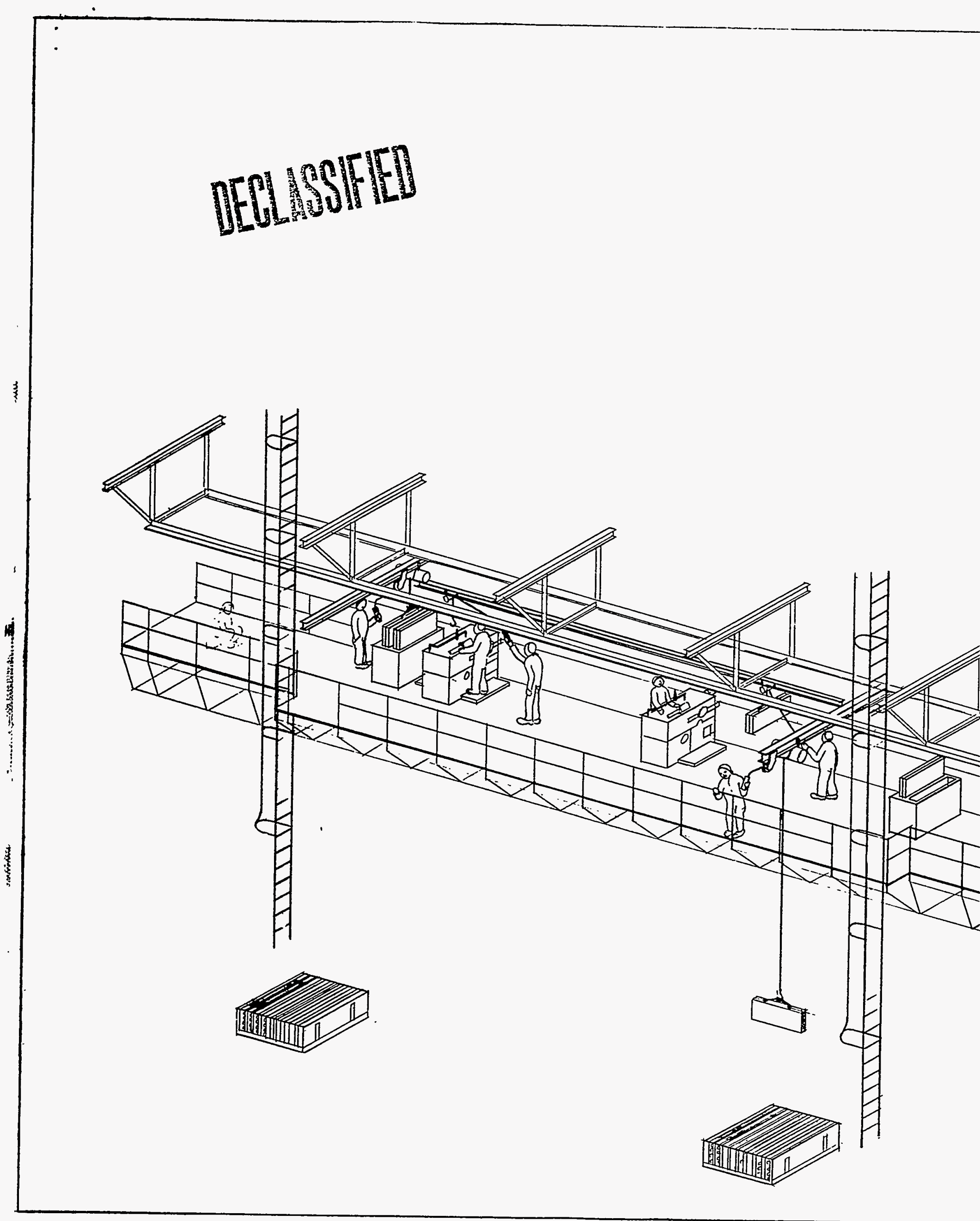




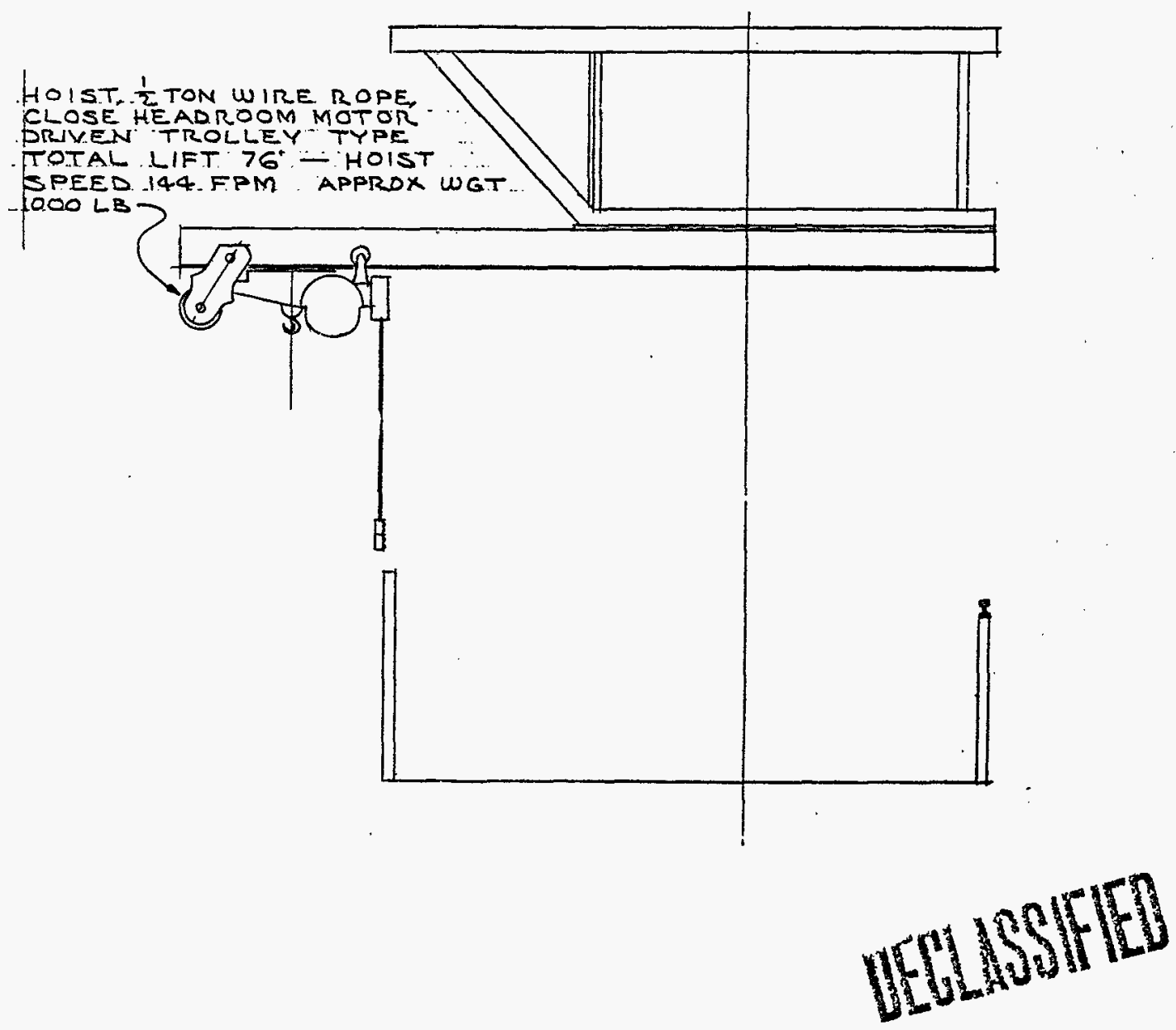

FIGURE - 2

FUEL HANDLING FACILITIES 


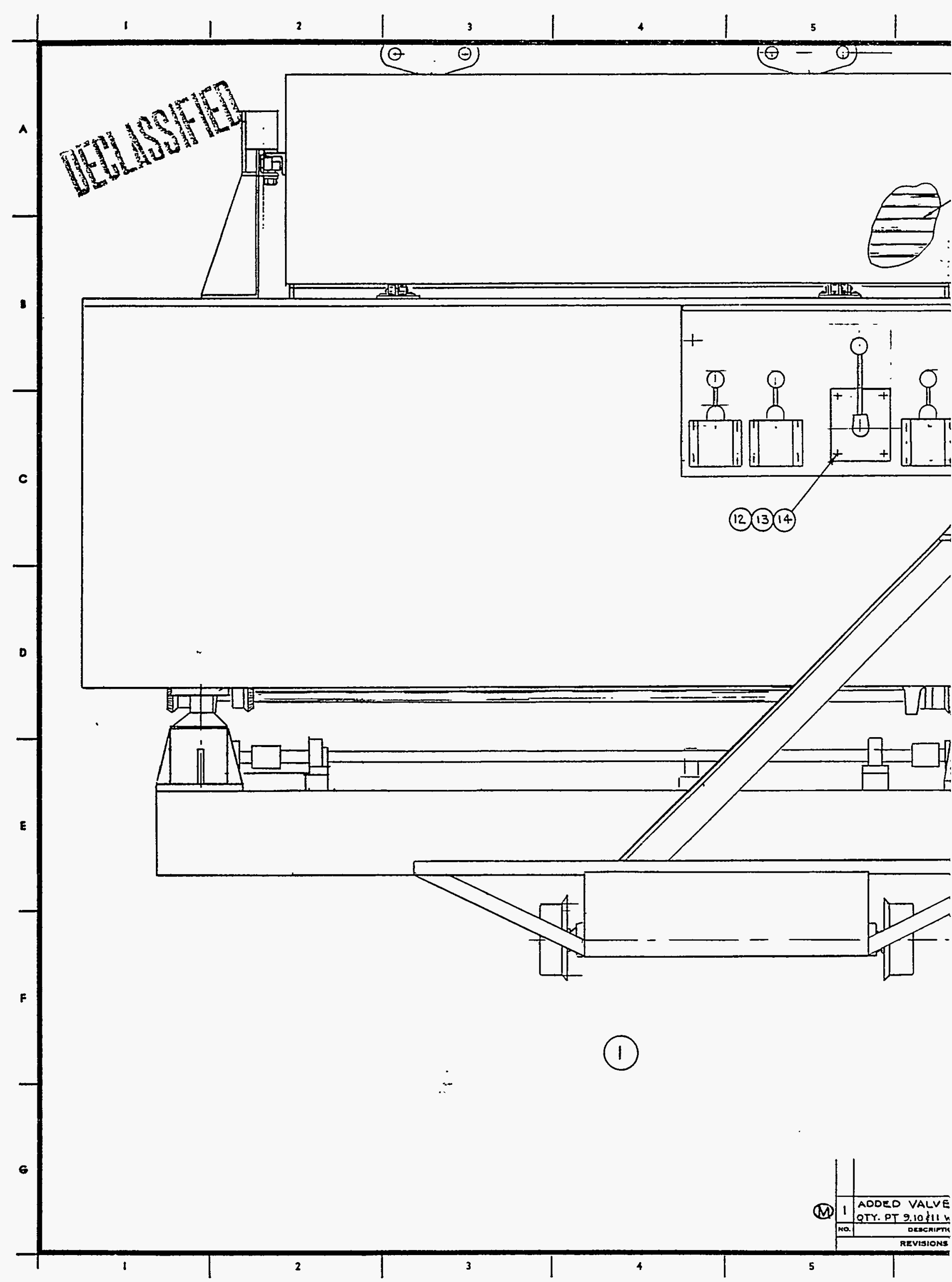


11

(4)

arr.

$m$

10

\begin{tabular}{|c|c|c|c|}
\hline$x$ & 1 & ASSEMBLY & \\
\hline 1 & 2 & CHARGER. & $H-1-33293$ \\
\hline 1 & 3 & CARRIAGE & $4.1-33311$ \\
\hline 4 & 4 & CARTON & $\mathrm{H}+1.33312$ \\
\hline & 5 & MAGAZINE ASST & $H-1-33299$ \\
\hline 1 & 6 & VALVE PANEL & $m-1-33318$ \\
\hline 2 & 7 & $\begin{array}{l}\text { HEX HO CAP SCREW } \\
\text { 16 UNG- } 2 B \times 2 \frac{1}{2} \text { LS }\end{array}$ & ST G.CA. \\
\hline 2 & 8 & LOCKWASHER YNOM. MEO & STL.C.Q. \\
\hline 20 & 9 & $\begin{array}{l}\text { SOC.HO CAP SCREW } \\
10-24 \text { UNC- } 2 A \times \$ L E\end{array}$ & STL. C.Q. \\
\hline 20 & 10 & HEX NUT 10.24 UNC-28 & STL. C.a. \\
\hline 20 & 11 & LOCKWASHER TO NOM MEO. & STL. C.Q. \\
\hline 4 & 12 & $\begin{array}{l}\text { SOC.HO. CAP SCREW } \\
\text { IS-18 UNE- } 2 A x+46 .\end{array}$ & STL. C.Q. \\
\hline 4 & 13 & HEX. NUT F-18UNC.20 & ET. C.Q. \\
\hline 4 & 14 & LOCK WASHERIE NOM. MED. & STL. C.Q. \\
\hline
\end{tabular}

for valves see dwg

- H-1-33313

$H W-7390.6 R D$

CUT HOLE AS REQ'D.

PAGE /6

(2) (7) (B) TAP PART 2 AT ASSY

(6)

(2)(10)(11)
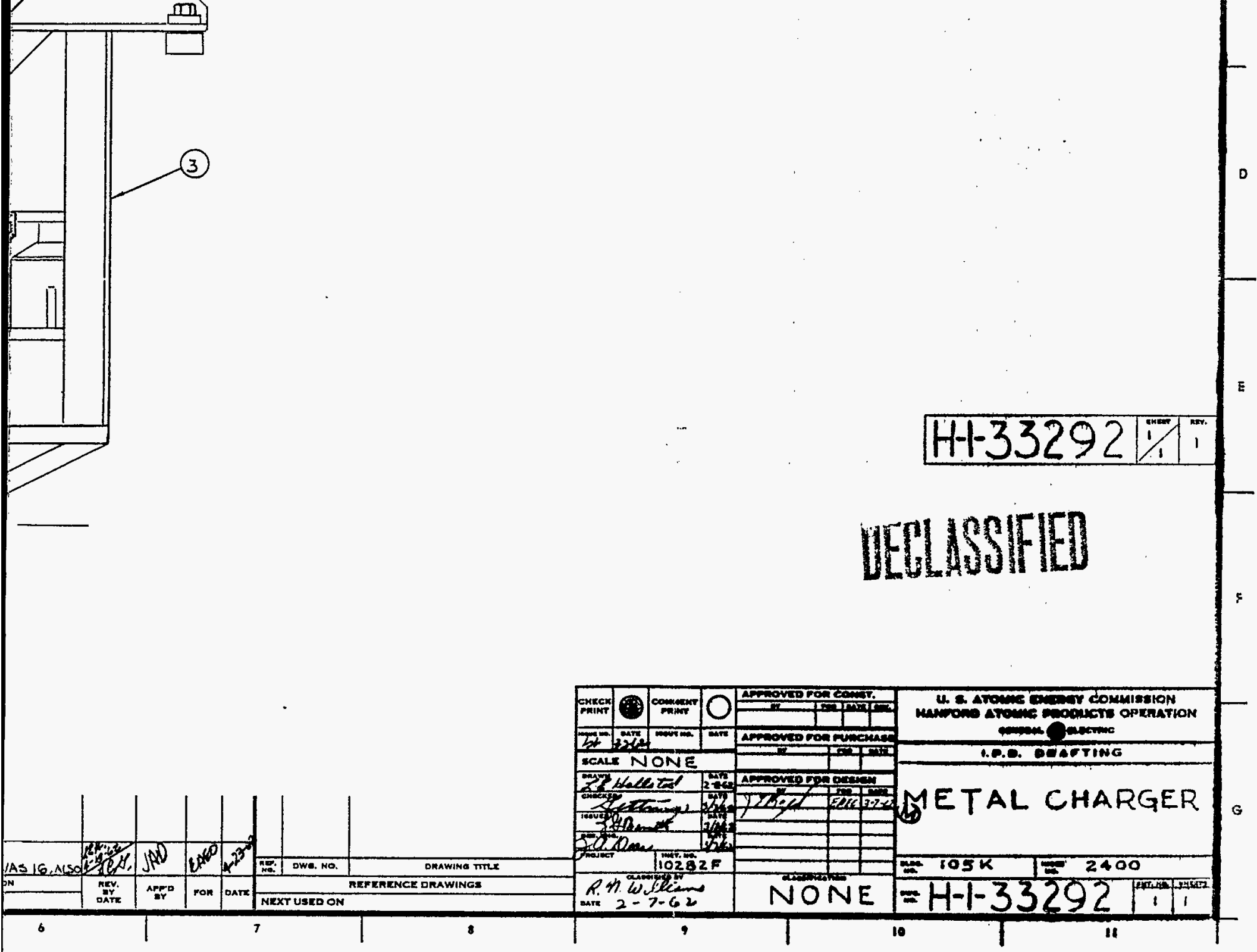


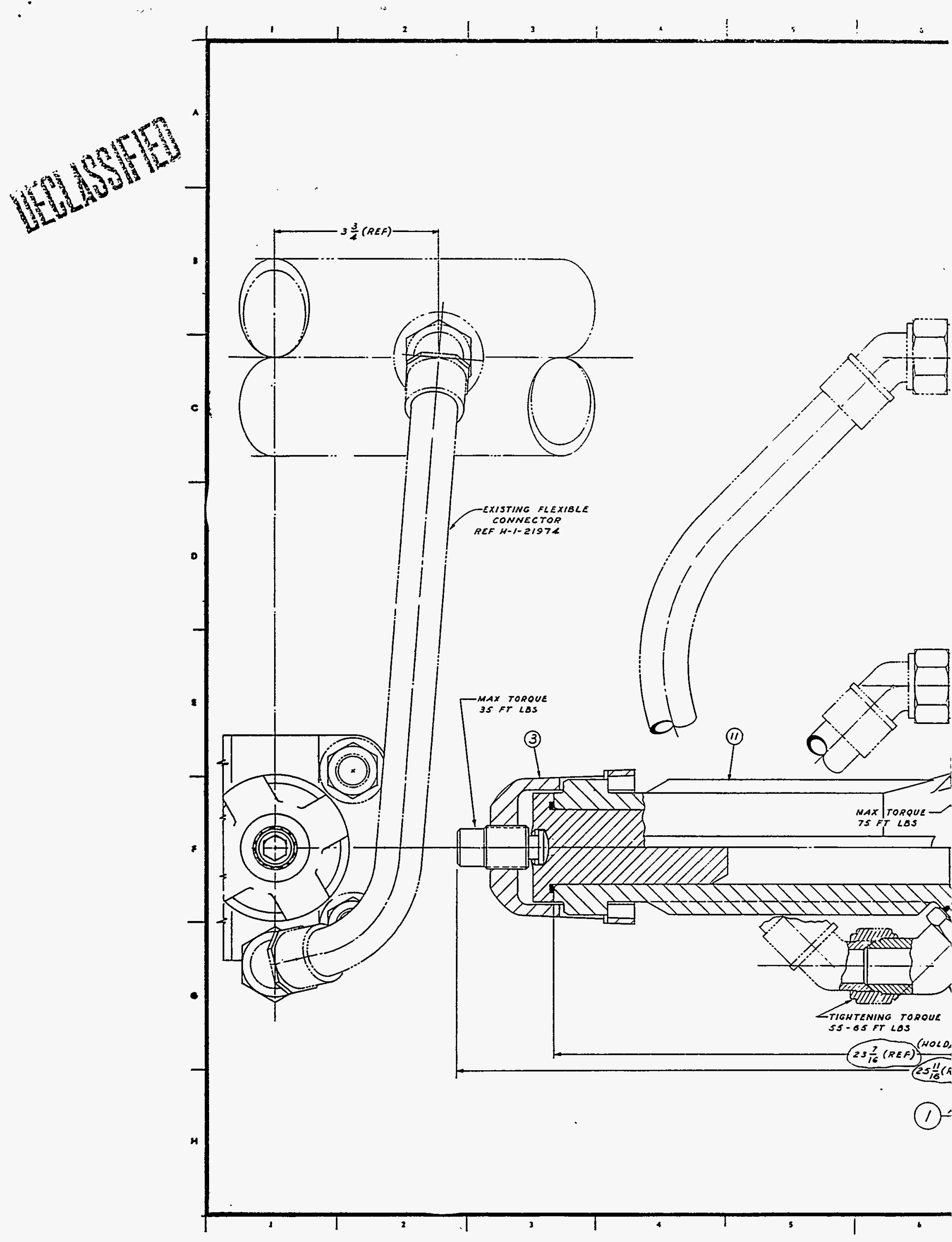




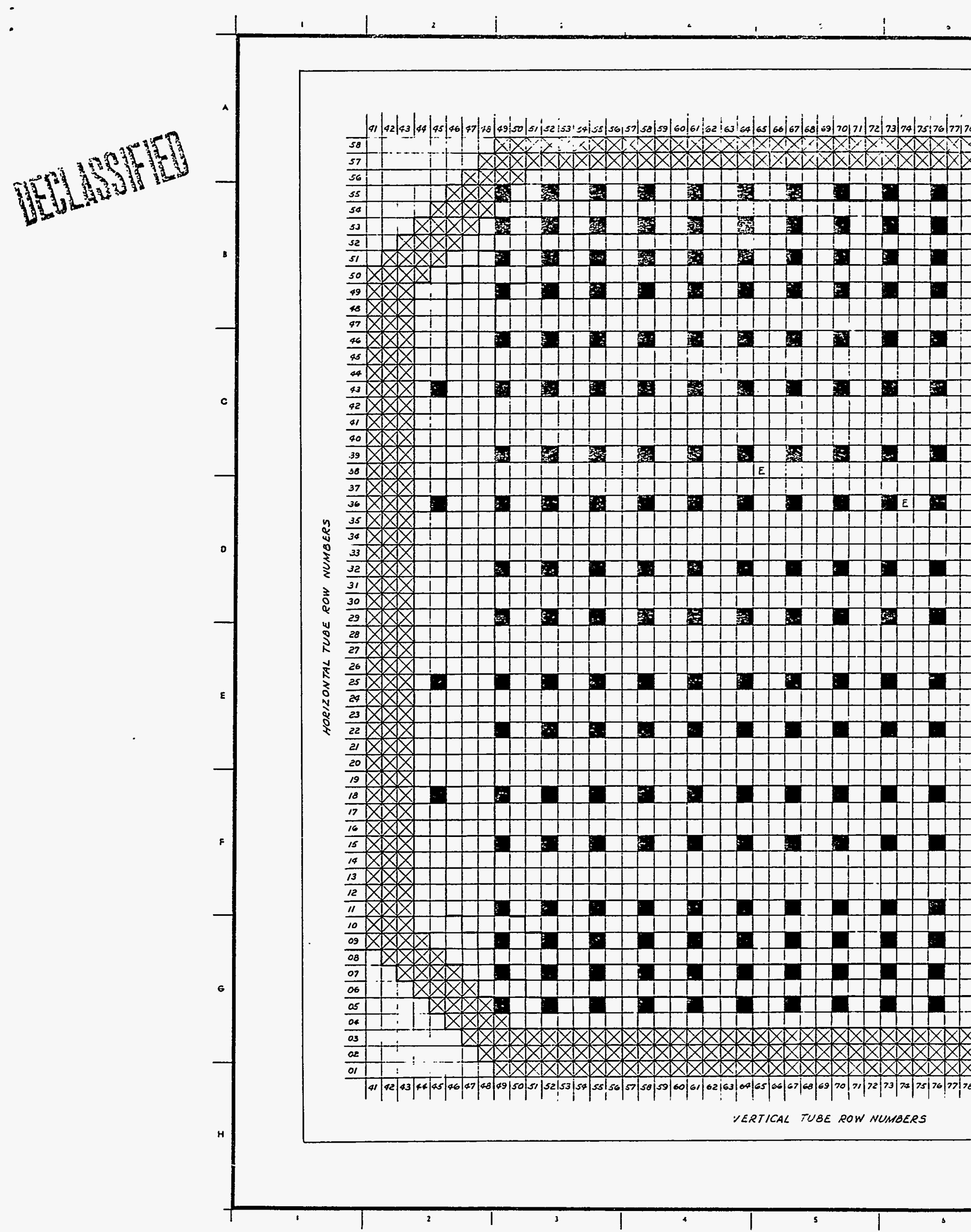




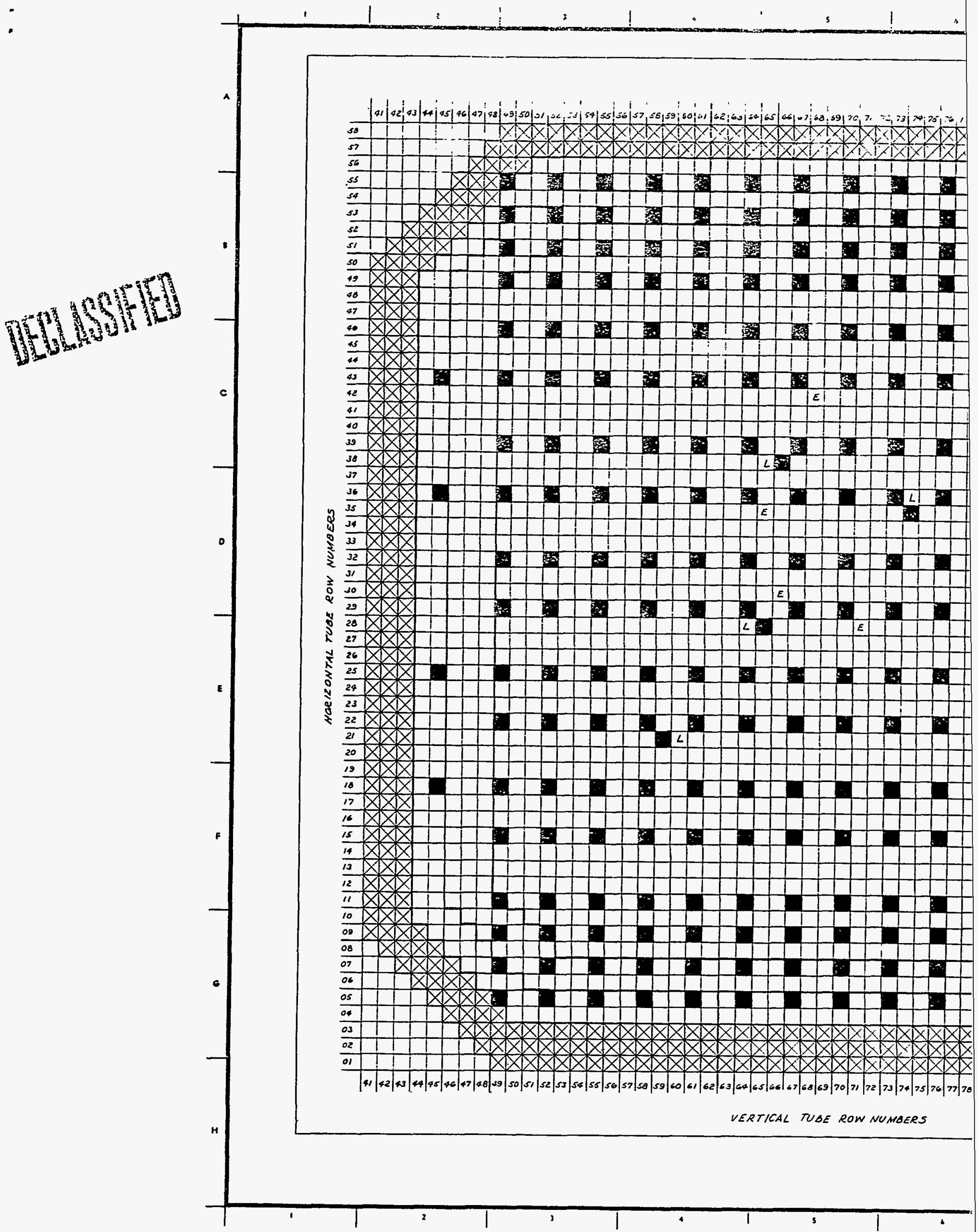


